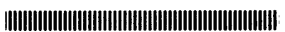

Original Paper

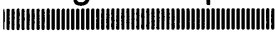

\title{
Effects of Weave Structure on the Mechanical Properties and Handle of Fabric
}

\author{
MORINO Hitomi*, YAMAOKA Akiyoshi*, \\ FURUTANI Minoru**
}

* Graduate school of Home Economics, Kobe Women 's University, Aoyama, Higashisuma, Suma-ku, Kobe, 654-8585, Japan

** Hyogo Prefectural Institute of Industrial Research, Uenodan, Nomura-cho, Nishiwaki, 677-0054, Japan

Received 1 October 2002 ; accepted for publication 27 May 2003

\begin{abstract}
In this study we investigated the effect of textile structure on mechanical properties and hand values of textile fabrics. Samples used were single cloth in which only textile structure was changed, and having the same yarn and the same density. We investigated correlation between mechanical parameters, hand values and textile structure result by using statistical method. Moreover, we derived estimation equation of mechanical parameters and hand values from the textile structure. It was found that there were effects of textile structure on both mechanical parameters and hand values. Those parameters could be estimated from the textile structure, using multiple regression equation. As a result of principal component analysis, $1^{\text {st }}$ and $2^{\text {nd }}$ component were obtained which mean fabric softness and surface feeling, respectively. Further, it was found that fabrics were classified into three groups such as hard plain weave, soft satin weave, and other weaves. Correlation between textile structure and those parameters was studied.
\end{abstract}

Key Words: Crossing - over Firmness Factor (C.F.F.), Average Floating Length (A.F.L.), Mechanical Parameter, Hand Values

\section{織物の力学的性質と風合いに及ぼす織物組織の影響}

\section{森野ひとみ* 山岡昭美* 古谷 稔**}

\section{1. 緒 言}

最近、川端・丹羽らの開発した「KESーFB システム」 [1][2][3]を用いて織物の力学的性質、風合いに関する研究が 行われ、多数の報告がみられる。すなわち、松平・埴生らは、 布の力学的特性および風合いに及ぼす洗濯[4]、絽り返し着用 の影響[5]について、日本産業皮虐衛生協会は、布の力学的特 性および風合いに及ぼす樹脂加工の影響、さらにそれらの皮 膚刺激への影響[6]について、松平は、布の力学的特性および 風合いに及ぼす最終仕上げ処理の影響[7]についてなどがあ る[8][9][10]。しかし、いずれも加工布および素材についての 研究であり、織物組織の構造自体による影響についての研究 は、まだ少ない。

そこで、本研究では、同一系使い、同一密度で、織物組織 のみ変化させた一重織物を用いて、それらの織物組織が、力 学的性質、風合いにどのような影響を及ぼすかについて検討 した。また、それらの結果の相関性を統計的手法により検討 し、さらに、織物の設計に役立てるために力学的特性值、基 本風合い值の予測式を算出した。その結果、基礎的知見を得 たので報告する。

\section{2.試料および実験}

2. 1 試 料

用いた布は、たて糸綿 100 番手双糸、よこ糸ポリエステル フィラメントで、フィラメント数の異なる 2 種類の引き揃え 釆（75d/24f・75d/48f）である。それぞれの布に異なる織物 組織布 10 種類（平織・ $2 / 2$ 斜文織・ 5 枚朱子織・砂子織・ ハック織・特別蜂巣織・スポンジ織・花岡織・昼夜斜文織・ 10 枚朱子織）を用い、供試試料とした。ただし、試料は、全 て一重組織であり、密度は、たて 120 本/inch、よこ 85 本/inch と同一系使い、同一密度である。それらの組織図を Table 1 に示す。三原組織である平織は、丈夫な織物であり、2/2 斜文 織は、布面に㑼が表われ、5枚朱子織は、たて系とよこ系の 交錯する箅所が少なく、系の浮きが長いため、柔軟な組織で あるという特徵がある [11]。その他の織物は、変化組織に属 する。すなわち、砂子織、ハック織、特別蜂巣織は平織の変 化組織に属し、スポンジ織は平織と斜文織を混合させた変化 組織に、花崗織、昼夜織は斜文織の変化組織に、10 枚朱子織 は、朱子織の変化組織に属する。そのため、それぞれ誘導さ れた三原組織の特徽が混合されている。 


\section{2 . 2 実験方法}

2. 2.1 織物の組織構成の算出法

（1）交錯堅確度 (Crossing-over Firmness Factor $=$ C.F.F.)の算出法

織物組織において、組織中間点、すなわち織目空間を中心 としたたて系 2 本、よこ系 2 本の計 4 本の系の交鍇状態を調 バ、交錯点の型を決め、各型にそれぞれウエイトをつけた表 を Table 2 に示す[12]。これらを元に交錯堅確度[12]を求め た。その算出の詳細過程と結果を Table 3 に示す。ただし、 完全組織は各織物により本数が異なるため同一本数で比較 する必要があるので、(3)では、まず各織物の完全組織内の本 数の最小公倍数を求めた。すなわち、たて系は 1680 本、よ こ系は 240 本である。

\section{（2）平均浮き長(Average Floating Length = A.F.L.)の算出法}

まず、浮きの型を決め、各型にそれぞれウエイトをつけた 表を Table 4 に示す。Table 4 を用いて、各織物の完全組織 内の浮きの型および浮き数を求め、次に、各型の浮きの長さ は、織物表面を KEYENCE 製の高精細デジタルマイクロス コープ VH-6300 で観察した写真より各型について 100 ヶ所 の浮きの長さを実測した值の平均值である。ここで、完全組 織は各織物により本数が異なるため、同一本数で比較する必 要があるので各織物の完全組織内の本数の最小公倍数を求 めた。すなわち、たて糸は 1680 本、よこ糸は 240 本である。 たて糸、よこ糸それぞれの平均浮き長は、以下に示す(1)式(2) 式より算出し、それらの平均値を平均浮き長とした。その結

Table 1 Various Design of Textile Weaves.

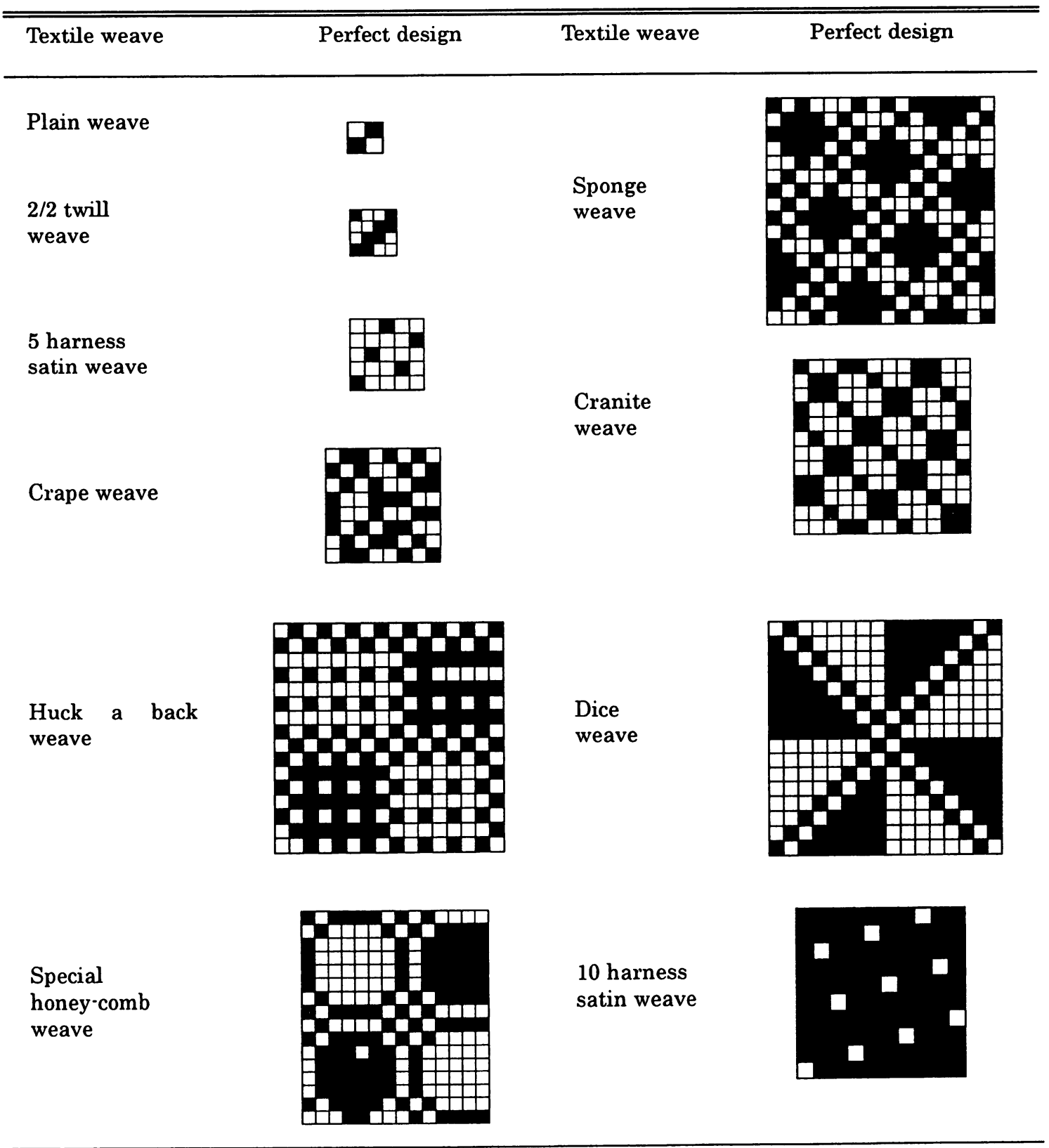


Table 2 Crossing-over Conditions of Textile Weaves.

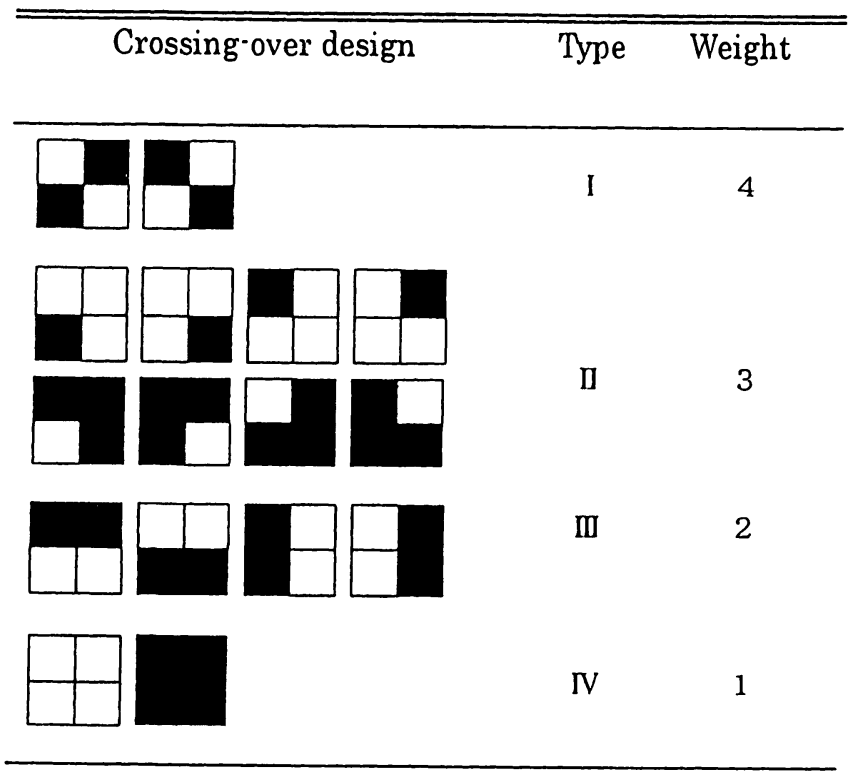

果をTable5に一括して示す。ここで、たて糸よこ糸それぞ れの平均浮き長を(1)、(2)に示し、平均浮き長を(3)に示す。

$$
\begin{aligned}
& \mathrm{d}_{1 \sim \mathbb{N}} \times(1680 / \mathrm{e}) \times(240 / \mathrm{f})=\mathrm{g} \\
& \mathrm{d}: \text { : 完全組織内の浮き数 } \\
& \mathrm{e}: \text { 完全組織内のたて糸本数 } \\
& \mathrm{f}: \text { 完全組織内のよこ系本数 } \\
& \mathrm{g}: \text { 最小公倍数の浮き数の合計 }
\end{aligned}
$$$$
(h \times g \times \text { Weight }) / g=i
$$

h：各型における浮きの長さの実测平均佔 $\mathrm{i} ：$ たて糸または、よこ系の平均浮き長

\section{2.2 織物の力学的特性值の測定法}

客微的評亚法すなわち、「KES-FBシステム」を用いて高感 度条件によって織物の基本力学的特性すなわち、引張り特 性、曲げ特性、せん断特性、圧縮特性、表而特性を測定した。

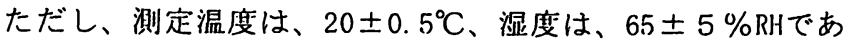
る。

\section{2.3 織物の基本風合い值の算出法}

基本風合い值すなわち、KOSHI - HARI - SHARI - FUKURAMI • SHINAYAKASA・KISHIMI を力学量一基本風合い値評価式により 算出した。ただし、評洒式は、KN-202-LDY[13]である。

\section{3、実験結果および考察}

織物の組織楧成を示す特性值として、交鍇堅碓度と平均浮 き長をとり上げることにした。

\section{1 交錯堅確度と平均浮き長}

交錯堅確度は、値が大きいほどたて糸とよこ糸の交錯する 回数が多い[12]。従って、今回の試料のように各織物のたて、 よこ密度が同一の場合の平織は、糸の交錯が多く、10 枚朱子 織は、糸の交錯が少ない。

平均浮き長は、值が大きいほど糸の浮きが長い。従って、 今回の試料のようにたてよこ密度が同一の場合の 10 枚朱子 織は、最も浮きが長く、平織は、最も浮きが短い。 交錯堅確㡲の值が大きくなるに従って、平均浮き長の值は、 小さくなる。すなわち、系の交錯が增えると、浮きが短くな る。

次に、その特性値間の関係を調べた結果を Fig. 1 に示す。 交錯堅確度と平均浮き長との間には負の相関がみられ、交錯

\begin{tabular}{|c|c|c|c|c|c|c|c|}
\hline \multirow[b]{2}{*}{ Textile weave } & \multicolumn{4}{|c|}{ (1) } & (2) & (3) & (4) \\
\hline & $I \times 4$ & $11 \times 3$ & III $\times 2$ & $\mathrm{IV} \times 1$ & $\begin{array}{l}\text { The number of C.F.F. } \\
\text { in the perfect design }\end{array}$ & $\begin{array}{l}\text { The number } \\
\text { of C.F.F. }\end{array}$ & C.F.F \\
\hline Plain weave & 16 & 0 & 0 & 0 & 16 & 1612800 & 100.0 \\
\hline $2 / 2$ twill weave & 0 & 48 & 0 & 0 & 48 & 1209600 & 75.0 \\
\hline 5 harness satin weave & 0 & 60 & 0 & 5 & 65 & 1048320 & 65.0 \\
\hline Crape weave & 104 & 60 & 32 & 2 & 198 & 1247400 & 77.3 \\
\hline Hack a back weave & 432 & 420 & 16 & 0 & 868 & 1367100 & 84.8 \\
\hline Special honey-comb weave & 256 & 72 & 116 & 78 & 522 & 939600 & 58.3 \\
\hline Sponge weave & 376 & 384 & 0 & 34 & 794 & 1250500 & 77.5 \\
\hline Cranite weave & 140 & 72 & 96 & 37 & 345 & 966000 & 59.9 \\
\hline Dice weave & 260 & 138 & 90 & 100 & 588 & 926100 & 57.4 \\
\hline 10 harness satin weave & 0 & 120 & 0 & 60 & 180 & 725760 & 45.0 \\
\hline
\end{tabular}
堅確度の值が大きくなるに従って、平均浮き長の値は、小さ くなる。すなわち、手の交錯が增えると、浮きが短くなるこ とが分かった。

Table 3 Calculations of C.F.F..

(1) $\cdots$ a $1 \sim N \times$ Weight a : 各織物、各型ごとの完全組織内の交錯点の数

(2) … Sum of (1)【完全組織内の交錯堅確度】

(3) … (2) $\times(1680 / \mathrm{b}) \times(240 / \mathrm{c})$ b : 完全組織のたて糸本数 c : 完全組織のよこ系本数

(4) $\cdots$ 平織の值を 100 とした比較数【C.F.F.】 


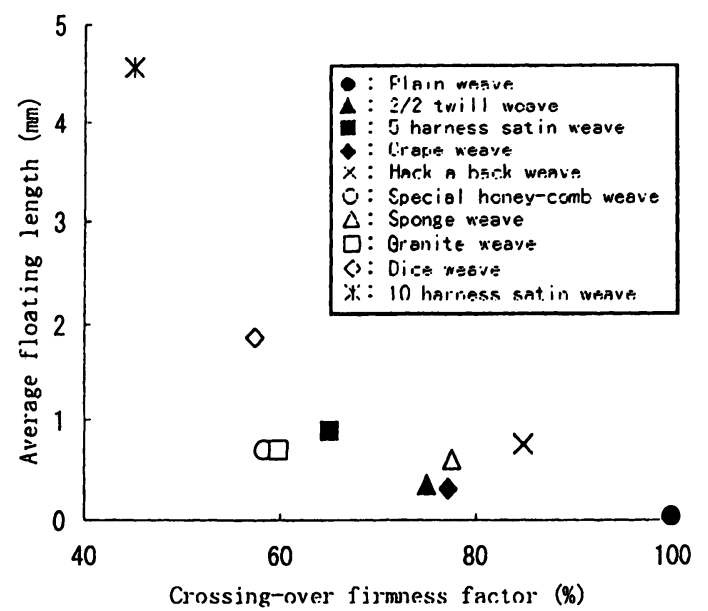

Fig. 1 Relationship between C.F.F and A.F.L. .

Table 4 Floating Conditions of Textile Weaves.

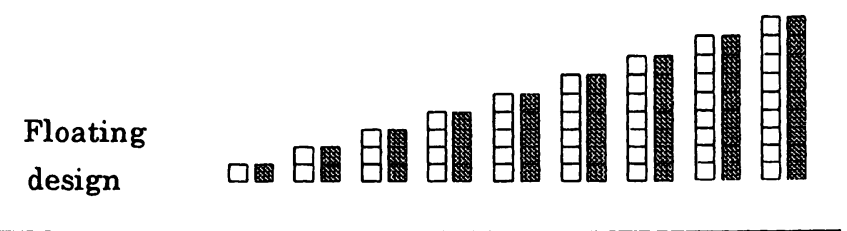

$\begin{array}{llllllllll}\text { Type } & \text { I } & \text { II } & \text { III } & \text { IV } & \text { V } & \text { VI } & \text { VII } & \text { VIII } & \text { IX }\end{array}$

\begin{tabular}{llllllllll} 
Weight & 0.1 & 1 & 2 & 3 & 4 & 5 & 6 & 7 & 8 \\
\hline
\end{tabular}

Table 5 Calculations of A.F.L..

\begin{tabular}{llll}
\hline \hline & & & \\
& & & \\
& & & \\
& & & \\
Textile weave & Warp & Weft & A.F.L. \\
\cline { 2 - 5 } & & & \\
Plain weave & 0.029 & 0.029 & 0.029 \\
2/2 twill weave & 0.344 & 0.344 & 0.344 \\
5 harness satin weave & 0.880 & 0.880 & 0.880 \\
Crape weave & 0.327 & 0.303 & 0.315 \\
Huck a back weave & 0.687 & 0.831 & 0.759 \\
Sponge weave & 0.597 & 0.597 & 0.597 \\
Special Honey-comb weave & 0.714 & 0.654 & 0.684 \\
Cranite weave & 0.686 & 0.686 & 0.686 \\
Dice weave & 1.866 & 1.866 & 1.866 \\
10 harness satin weave & 4.577 & 4.577 & 4.577 \\
& & & \\
\hline
\end{tabular}

\section{2 各種織物の基本力学的特性と組織構成と の関係について}

まず、各種織物の基本力学的特性すなわち、引張り特性、 曲げ特性、せん断特性、压縮特性、表面特性と組䋨構成すな 才ち、交鍇堅確度、平均浮き長との間の相關係数を求めた。 ただし、対数をとった值を用いた。その結果をTable 6 に示 す。ここで、*印は $5 \%$ 有意であることを示している。交鍇 堅碓度、平均浮き長の雨者が影響する力学的特性、雨者のう ちいずれか一方が影響する力学的特性、いずれにも影響され ない力学的特性の 4 通りがあることが分かる。

雨者がいずれにも影響する力学的特性は、雨試料ともに曲 げ剛性 B、せん断剛性 G、せん断ヒステリシス $2 H G$ 、同大変 形 $2 H G 5$ 、布の重量Wである。それに加え、75d/48f では、引 張り直線性 LT、曲げヒステリシス $2 H B$ 、表面摩擦係数 MIU も 影響する。

一例として曲げ剛性Bについて述べる。曲げ剛性 B と交錯 堅確度との関係を梌討した結果をFig. 2 に示す。正の相関が みられ、交錯堅確度が大きくなるに従って、曲げ剛性 B の值 が、大きくなり、曲げに対して、硬くなる傾向のようである。

Table 6 Correlation Coefficients

between Mechanical Parameters and Textile Structure Parameters (log).

\begin{tabular}{|c|c|c|c|c|c|}
\hline \multirow{2}{*}{\multicolumn{2}{|c|}{ Mech. Para. }} & \multirow{2}{*}{\multicolumn{2}{|c|}{$\begin{array}{r}75 \mathrm{~d} / 24 \mathrm{f} \\
\text { A. F. L.. }\end{array}$}} & \multicolumn{2}{|c|}{$75 \mathrm{~d} / 48 \mathrm{f}$} \\
\hline & & & & C.F.F & A. F. L. \\
\hline 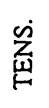 & $\begin{array}{l}\text { LT } \\
\text { IVT } \\
\text { RT }\end{array}$ & $\begin{array}{r}0.396 \\
-0.242 \\
-0.476\end{array}$ & $\begin{array}{r}-0.242 \\
0.106 \\
0.477\end{array}$ & $\begin{array}{r}0.706^{\circ} \\
0.097 \\
-0.398\end{array}$ & $\begin{array}{r}-0.814^{\circ} \\
-0.368 \\
0.248\end{array}$ \\
\hline$\sum_{\substack{a \\
\infty}}^{\circ}$ & $\begin{array}{l}\text { B. } \\
2 \mathrm{HB}\end{array}$ & $\begin{array}{l}0.759^{\circ} \\
0.614\end{array}$ & $\begin{array}{l}-0.924^{\circ} \\
-0.819^{\circ}\end{array}$ & $\begin{array}{l}0.831^{\circ} \\
0.706^{\circ}\end{array}$ & $\begin{array}{l}-0.893^{\circ} \\
-0.853^{\circ}\end{array}$ \\
\hline 岁 & $\begin{array}{l}\mathrm{G} \\
2 \mathrm{HC} \\
2 \mathrm{HC5}\end{array}$ & $\begin{array}{l}0.704^{\circ} \\
0.728^{\circ} \\
0.732^{\circ}\end{array}$ & $\begin{array}{l}-0.941^{\circ} \\
-0.935^{\circ} \\
-0.938^{\circ}\end{array}$ & $\begin{array}{c}0.719^{\circ} \\
0.758^{\circ} \\
0.751^{\circ}\end{array}$ & $\begin{array}{l}-0.946^{\circ} \\
-0.946^{\circ} \\
-0.936^{\circ}\end{array}$ \\
\hline 远 & $\begin{array}{l}\text { LC } \\
\text { WC } \\
R C \\
T\end{array}$ & $\begin{array}{r}0.214 \\
-0.230 \\
-0.275 \\
-0.078\end{array}$ & $\begin{array}{r}-0.413 \\
-0.416 \\
0.364 \\
0.345\end{array}$ & $\begin{array}{r}0.432 \\
0.508 \\
-0.307 \\
0.750^{\circ}\end{array}$ & $\begin{array}{c}-0.491 \\
-0.649^{\circ} \\
0.381 \\
-0.482\end{array}$ \\
\hline 岁 & $\begin{array}{l}\text { MIU } \\
\text { WND } \\
\text { SWD }\end{array}$ & $\begin{array}{r}-0.552 \\
0.301 \\
0.264\end{array}$ & $\begin{array}{l}0.807^{\circ} \\
-0.131 \\
-0.033\end{array}$ & $\begin{array}{r}-0.637 \\
0.376 \\
0.114\end{array}$ & $\begin{array}{r}0.849^{\circ} \\
-0.217 \\
0.069\end{array}$ \\
\hline $\begin{array}{l}\text { 岕 } \\
\text { 岕 } \\
\text { 岁 }\end{array}$ & $w$ & $0.670^{\circ}$ & $-0.889^{\circ}$ & $0.759^{\circ}$ & $-0.947^{\circ}$ \\
\hline
\end{tabular}


一方、曲げ剛性 B と平均浮き長との関倸を検討した結果を Fig. 3に示す。その結果、強い負の相関がみられ、平均浮き 長の值が大きくなるに従って、曲げ剛性 B の值が、小さくな り、曲げに対して、柔らかくなる傾向のようである。これら の結果から、曲け剛性 Bには、交錯堅確度と平均浮き長の両 者が関係すると思われるので、交錯堅確度 $\left(\mathrm{X}_{1}\right)$ 、平均浮き 長 $\left(\mathrm{X}_{2}\right)$ を説明変数として、SPSS $11.0 \mathrm{~J}$ for Windows を用 いて重回帰分析を行い、重回帰式を求めた。ただし、生デー 夕のままの変数では、各変量の単位や析数が異なるものが多 いので、その影響を排除するために標淮化した值を用いた (以下同様) [14]。その結果、得られた重回帰式は、

$75 \mathrm{~d} / 24 \mathrm{f}$ の場合、 $\mathrm{B}=+0.861 \mathrm{X}_{1}+0.125 \mathrm{X}_{\mathrm{z}}$ であり、 $75 \mathrm{~d} / 48 \mathrm{f}$ の場合、 $B=+0.881 X_{1}+0.055 X_{2}$ である。ここで、標淮偏回帰 倸数の値を比较すると、両試料とも交鍇堅確度の值の方が、 平均浮き長の值より大であり、交錯堅確度の方が曲げ剛性 $\mathrm{B}$ 一の影響は大であることが分かった。さらに交錯堅確度およ び平均浮き長の值が分かれば、求めた重回㷌式を用いて、曲 げ剛性 B の值を推定することが可能である。

例えば、 $75 \mathrm{~d} / 24 \mathrm{f}$ の $2 / 2$ 斜文織の曲げ剛性 B の值を推定す る場合、前述した重回帰式を用いて、 $X_{1}$ に、2/2 斜文織の 交錯堅確度の標準化值 0.192 を、 $\mathrm{X}_{2} に 2 / 2$ 斜文織の平均浮 き長の標準化值-0.563 を代入すると、曲げ剛性 B の值を求 めることができる。次に、実測值に戻す必要があるため、

（3）式を用いて変換した。ここで求まる值が実測值の予測 值Xである。これらの式の回㷌精度を調べた結果をFig. 4、 Fig. 5 に示す。その結果、どちらも重相関係数が高く、 「KES-FB システム」で測定した実測値とほぼ一致することが 分かった (両者とも $5 \%$ 有意水淮)。その他の力学的特性值 を予測する重回帰式の有用性を検討した結果、75d/48f の表 面摩摖係数 MII の重回帰式すなわち、MIU = $-0.085 X_{1}+0.732 X_{2}$ 【 $5 \%$ 有意水準】と布の重量Wの重回㷌式すなわち、

$W=+0.687 \mathrm{X}_{1}-0.138 \mathrm{X}_{2}$ 【 $5 \%$ 有意水準】である。重相関も高 く、 $F_{0}$ の值が F の限界值より大であり、有用性が認められた。

$$
\sigma \mathrm{Z}+\mu=\mathrm{X}
$$

$$
\begin{aligned}
& \sigma: \text { 母標淮偏差値 } \\
& Z: y \text { 值 (標準化した値) } \\
& \mu: \text { 母平均值 } \\
& \mathrm{X}: \text { 実測值の予测值 }
\end{aligned}
$$

次に、両者のうちいずれか一方が影響する場合、交錯堅確 度のみが影響する力学的特性は、75d/48f の布の厚さ Tのみ であり、平均浮き長のみが影響する力学的特性は、 $75 \mathrm{~d} / 24 \mathrm{f}$ の曲げヒステリシス $2 \mathrm{HB}$ 、表面摩擦係数 MIU と、 $75 \mathrm{~d} / 48 \mathrm{f}$ の 圧縮回復性WCである。これらの場合は、散布図を作成して、 回帰分析を行い、回帰式を求めれば良い。この回帰式を用い て力学的特性の推定が可能である。得られた単回㷌式の $\mathrm{x}$

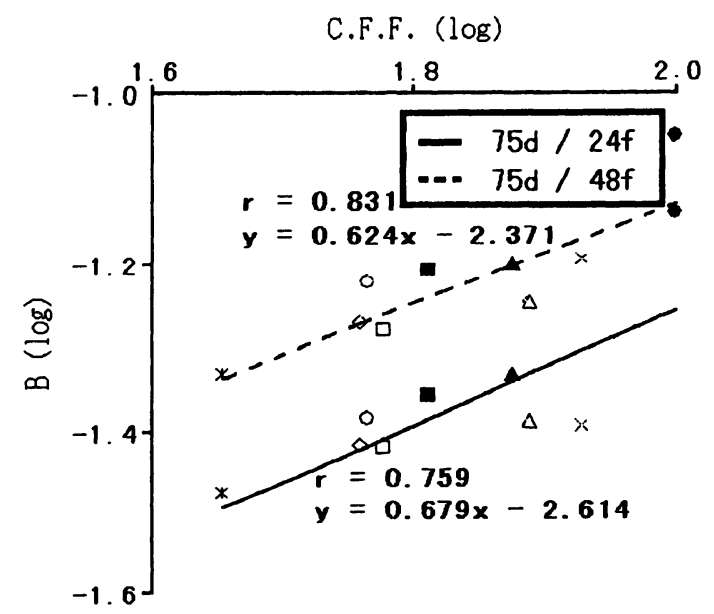

Fig. 2 Relationship between Bending Rigidity (B) and C.F.F. .

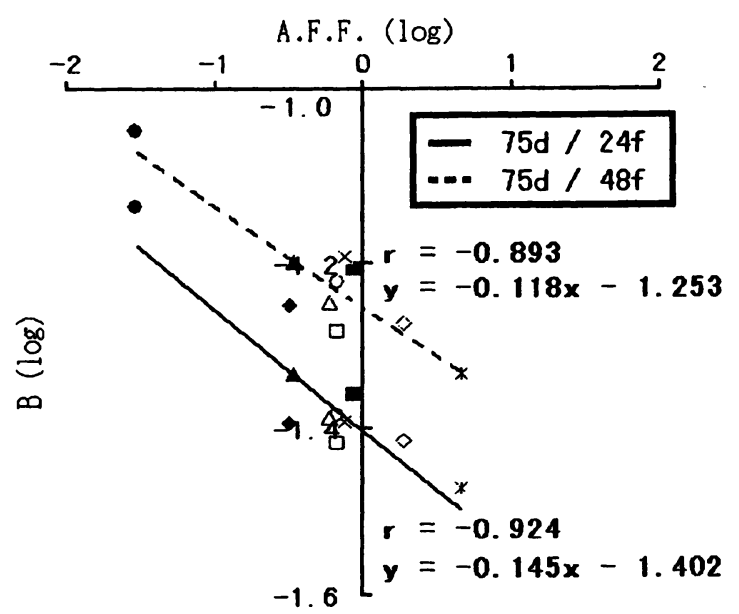

Fig. 3 Relationship between Bending Rigidity (B) and A.F. L. .

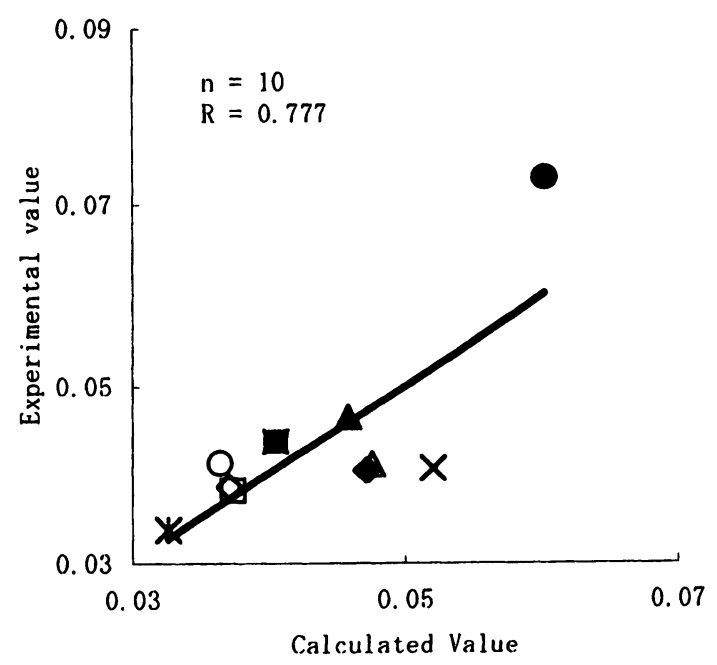

Fig. 4 Agreement of $B(75 d / 24 f)$. 


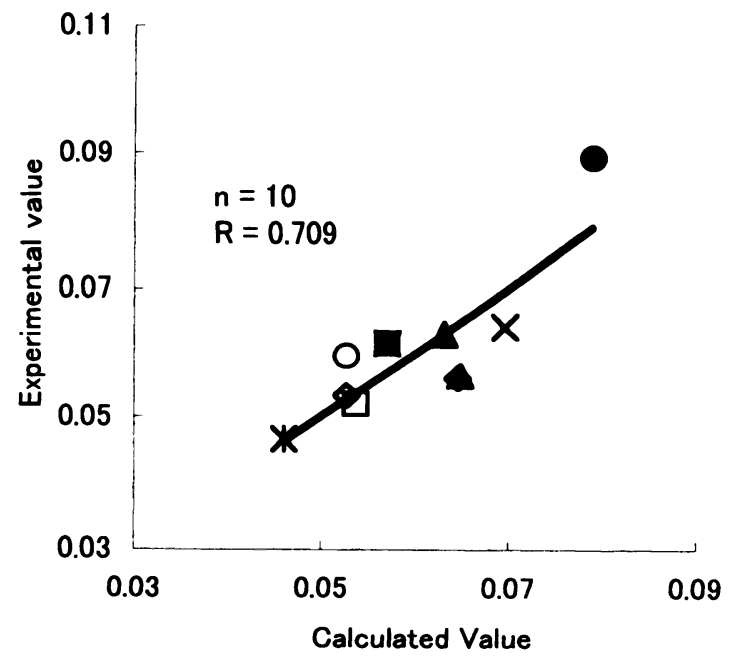

Fig. 5 Agreement of B (75d/48f).

交錯堅確度の值、または平均浮き長の值を代入すると、y 值の対数值を求めことができる。次に、実測值に戻す必要が あるため、（4）式を用いて変換した。

$$
10^{x}=y
$$

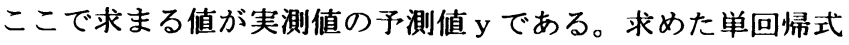
の有用性を検討するため、F検定を行った結果を一括して Table 7 に示す ( 5 \% 有意水準)。Table 7 に示す全ての単回帰 式の有用性が認められた。

いずれにも影響されない力学的特性は、両試料ともに引張 り仕事量WC、引張り弾性回復性RT、圧縮直線性LC、圧縮弾性 回復性RC、表面摩擦係数の変動MMD、表面粗さSMDである。そ れに加え、 $75 \mathrm{~d} / 24 \mathrm{f}$ の引張り直線性LT、圧縮仕事量WCも影響さ れないことが分かった。

\section{3 各種織物の基本風合いと組織構成との関 係について}

まず、各種織物の基本風合い值すなわち、KOSHI・HARI・ SHINAYAKASA・FUKURAMI・SHARI・KISHIMI と組織構成との間の 相関係数を求めた。その結果をTable 8 に示す。ここで、*印 は $5 \%$ 有意であることを示している。交錯堅確度、平均浮き 長の両者が影響する基本風合い、両者のうち一方が影響する 基本風合い、いずれにも影響されない基本風合いの 3 通りが あることが分かる。両者がいずれにも影響する基本風合いは、 両試料ともにHARI、SHINAYAKASAである。それに加え、75d/48f ではFUKURAMIも影響する。

一例としてHARI について述べる。HARI と交錯堅確度との 関係を検討した結果をFig. 6 に示す。強い正の相関がみられ、
Table 7 Simple-regression Eqution and F-values.

\begin{tabular}{|c|c|c|}
\hline $\begin{array}{l}\text { Yarn } \\
\text { filament }\end{array}$ & $\begin{array}{l}\text { Simple-regression } \\
\text { equation }(\log )\end{array}$ & $\mathrm{F}_{0}$ \\
\hline $75 \mathrm{~d} / 24 \mathrm{f}$ & $2 \mathrm{HB}=-0.157 \mathrm{x}_{\text {A. F. L. }}-1.502$ & 27. $178^{*}$ \\
\hline $75 \mathrm{~d} / 24 \mathrm{f}$ & $M I U=+0.079 x_{\text {A. F. L. }}-0.729$ & 104. $777^{*}$ \\
\hline $75 d / 48 f$ & $W C=-0.050 x_{\text {A. F. L. }}-1.390$ & 168. $110^{*}$ \\
\hline $75 \mathrm{~d} / 48 \mathrm{f}$ & $T=-0.025 x_{\text {C.F.F. }}-0.799$ & $11.117^{*}$ \\
\hline
\end{tabular}

Table 8 Correlation Coefficients between Hand Values and Textile Structure Parameters (log).

\begin{tabular}{|c|c|c|c|c|}
\hline \multirow[b]{2}{*}{ Hand value } & \multicolumn{2}{|c|}{$75 \mathrm{~d} / 24 \mathrm{f}$} & \multicolumn{2}{|c|}{$75 d / 48 f$} \\
\hline & C.F.F & A. F. L. & C.F.F & A. F. L. \\
\hline KOSHI & 0.564 & -0.601 & 0.568 & $-0.653^{*}$ \\
\hline HARI & $0.763^{*}$ & $-0.882^{*}$ & $0.883^{*}$ & $-0.894^{*}$ \\
\hline SHINAYAKASA & $-0.692^{*}$ & $0.837^{*}$ & $-0.807^{*}$ & $0.843^{*}$ \\
\hline FUKURAMI & -0.068 & 0.008 & $-0.777^{*}$ & $0.717^{*}$ \\
\hline SHARI & -0.208 & 0.479 & -0.191 & 0.465 \\
\hline KISHIMI & -0.351 & 0.319 & -0.525 & 0.553 \\
\hline
\end{tabular}

$* r(8,0.05)=0.631$

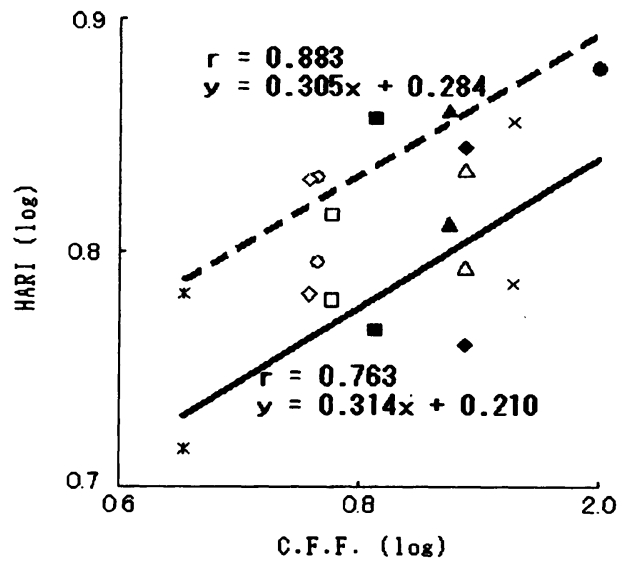

Fig. 6 Relationship between HARI and C.F.F. . 


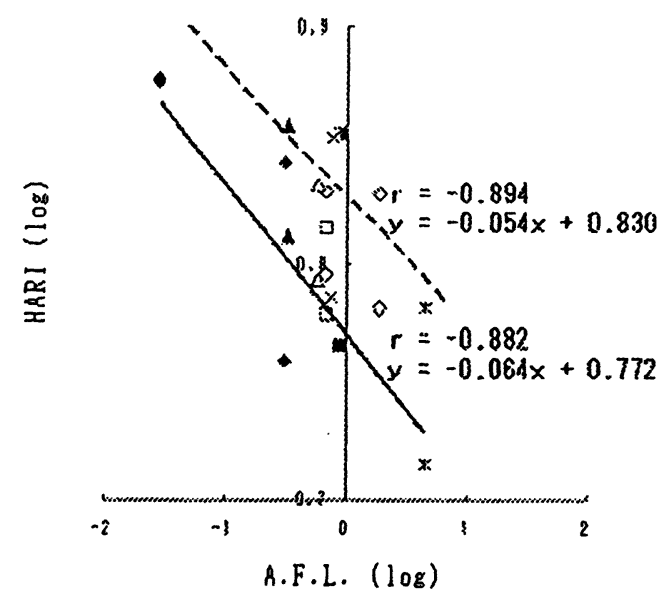

Fig. 7 Relationship between HARI and A.F.L.

交錯堅確度が大きくなるに従って、HARIの值が、大きくな り、HARIの感覚が強くなる傾向のようである。一方、Fig. 7 に、HARIと平均浮き長との関係を榆討した結果を示す。その 結果、強い負の相関がみられ、平均浮き長の値が小さくなる に従って、HARIの值が、小さくなり、HARIの感覚が弱くなる 傾向のようである。これらの結果から、HARIには、交鍇堅確 度と平均浮き長の雨者が関係すると思われるので、交鍇堅確 㡲 $\left(X_{1}\right)$ 、平均浮き長 $\left(X_{2}\right)$ を説朋変数として、重回帰分 析を行い、重回帰式を求めた。ただし、祭準化した值を用い た。その結果、得られた重回帰式は、75d/24fの場合、 HARI $=+0.630 \mathrm{X}_{1}-0.207 \mathrm{X}_{2}$ 【5\%有意水準】であり、75d/48f の場合、HARI $=+0.797 \mathrm{X}_{1}-0.126 \mathrm{X}_{2} 【 5 \%$ 有意水隻】である。 ここで、㴪隻偏回帰係数を比较すると、両試料とも交鍇堅確 度の值の方が、平均浮き長の值より大であり、交錯堅確度の 方がHARIへの影響は大であることが分かった。さらに交錯堅 確度および平均浮き長の值が分かれば、水めた重回帰式を用 いて、前述した方法で、HARIの值を推定することが可能であ る。また「KES FBシステム」で测定した実测值とほぼ一致す ることが分かった（雨者とも5\%有意水潐)。

次に、雨者のうち一方が影響する場合、交鍇啓確度のみが 影響する基本風合いは全くなく、平均浮き長のみが影響する 基本風合いは、75d/48fのKOSHIである。この場合も前述した 方法で散布図を作成して、回帰分析を行い、回帰式を求めれ ば良い。この回㷌式を用いて基本風合い値の推定が可能であ る。冰めた単回㷌式の有用性を検討するため、下検定を行った 結果、䍶回㷌式の有用性が認められた ( $5 \%$ 有意)。

\section{4 力学的特性値および基本風合い值の規格 化による考察}

Fig. 8、Fig. 9 に各種織物の力学的特性値および基本風合 い值を規格化して、婦人用薄手布の母集団と対比して榆討 した結果を示す。

Mach. Para.

$$
x_{i}=\left(x_{i}-\bar{x}_{i}\right) / \sigma_{i}
$$

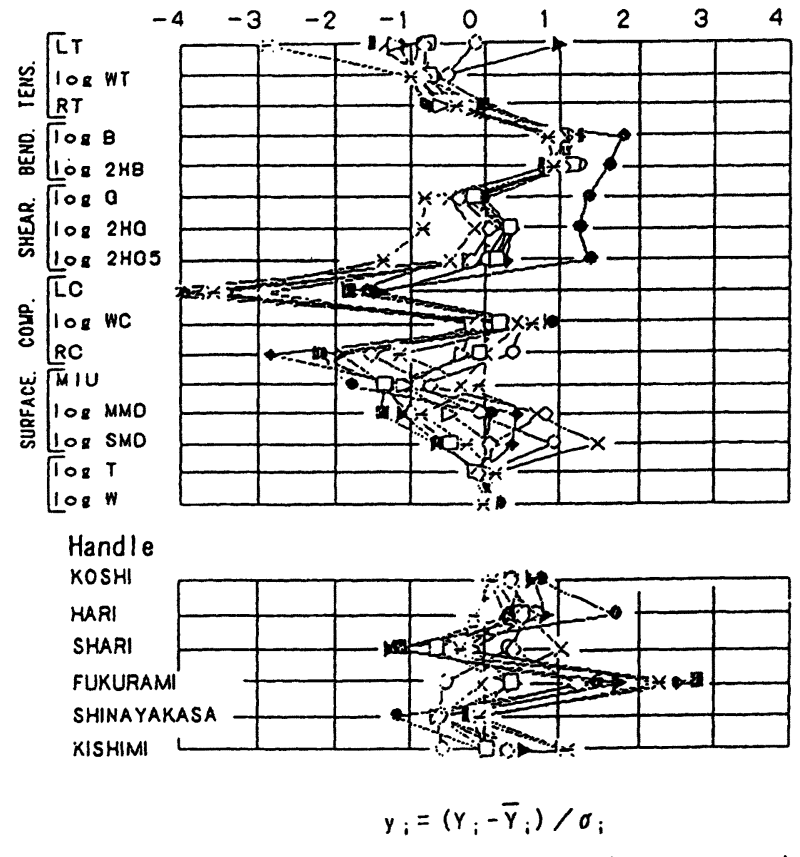

$(K N-202-L D Y)$

Fig. 8 Machanical Parameters and Hand Values of Textile Weaves (75d/24f).

Mach. Para. $\quad x_{i}=\left(x_{i}-\bar{x}_{i}\right) / \sigma_{i}$

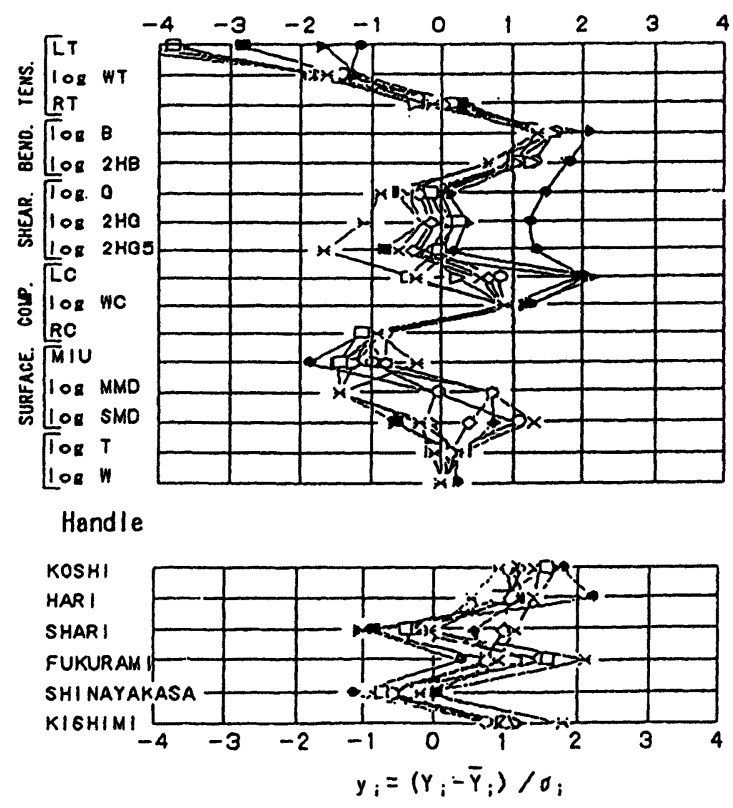

$(K N-202-L O Y)$

Fig. 9 Machanical Parameters and Hand Values of Textile Weaves (75d/48f). 
まず、力学的特性值について考察する。いずれの織物も、 その力学的特性值は、 $2 、 3$ をのぞき、ほとんど婦人用薄手 布の母集団に入っていることが分かった。母集団からの外れ の大きいものは、75d/24f の圧縮值線性LCと $75 \mathrm{~d} / 48 \mathrm{f}$ の引張り 直線性LTである。しかし、どちらも柔らかくなる方向である ので、それほど大きな問題ではない。

基本風合い值について考察する。いずれの織物も婦人用薄 手布の母集団に入っていることが分かった。

全体的にみて、平織は、KOSHI、HARIの感覚が強く、 SHINAYAKASAの感覚が弱いことが分かった。一方、10枚朱子織 は、平織と反対の結果であった。

\section{5 主成分分析による考察}

各種織物の力学的特性値、基本風合い值および組織構成 の値を用いて、主成分分析により解析した [15][16][17]。 まず、相関行列から求めた固有值をTable 9 に示す。第 1 主成分の固有值 $\lambda_{1}$ は4. 685 、第 2 主成分の $\lambda_{2}$ は1.973であ る。ここで、第 2 主成分までの累積寄与率は、約 $70 \%$ あ゙あ り、固有值が分散の基準である1.0を超えているので、第 2 主成分までを考えることにした。次に、主成分の因子負 荷量を求め、これらの值を散布図にプロットした結果を Fig. 9 に示す。ただし、標準化した值を用いた。この散布 図で接近している変数同士は、関係が深く、原点に対して 反対側にある変数同士は、負の相関がある。また、原点に

Table 9 Eigenvalue.

\begin{tabular}{cccc}
\hline $\begin{array}{c}\text { Principal } \\
\text { Component }\end{array}$ & Eigenvalue & $\begin{array}{l}\text { Contribution } \\
\text { ratio }\end{array}$ & $\begin{array}{l}\text { Cumulative } \\
\text { Contribution ratio }\end{array}$ \\
\hline 1 & 4.685 & 0.520 & 0.520 \\
2 & 1.973 & 0.219 & 0.739 \\
3 & 0.878 & 0.097 & 0.837 \\
4 & 0.442 & 0.049 & 0.886 \\
5 & 0.337 & 0.037 & 0.923 \\
6 & 0.278 & 0.031 & 0.954 \\
7 & 0.135 & 0.015 & 0.969 \\
\hline
\end{tabular}

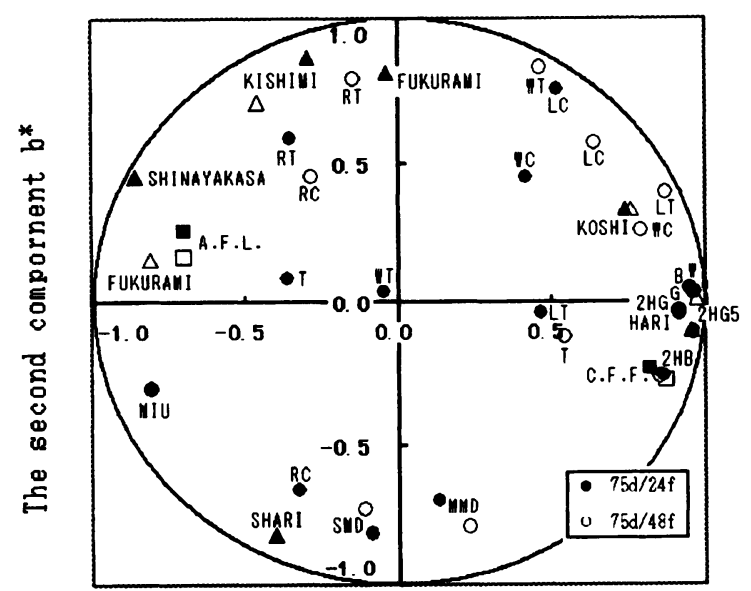

The first compornent $a^{*}$

Fig. 10 Factor Loading Plot.

(Standardized values were used.)

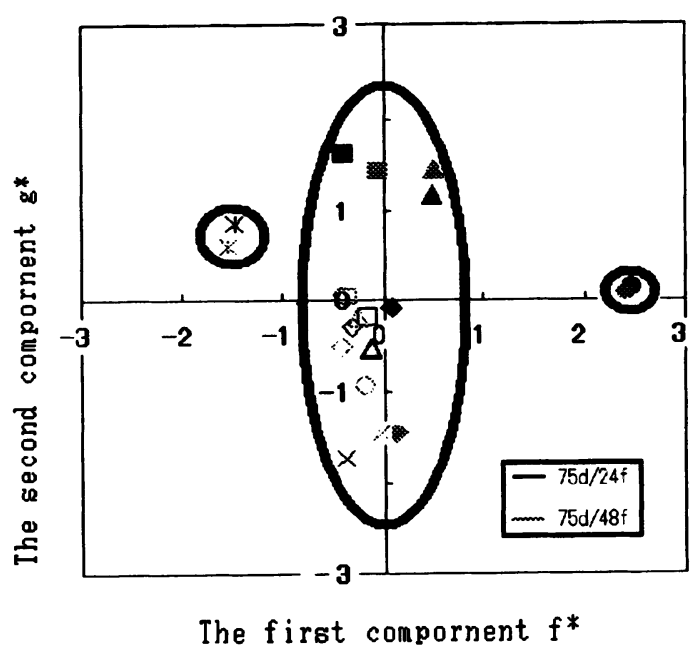

Fig. 11 Component Score Plot.

(Standardized values were used.) 
対して直角の位置にある変数同士は、無関係であることを示 す。第 1 主成分 $a *$ の軸は、布のソフトさを示す指標といえ、 第 2 主成分b*の軸は、表面状態の感覚を示与指標といえる。 さらに、各試料の特徵を調べるために、主成分得点を求めた。

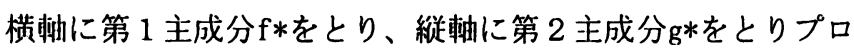
ットした結果をFig. 10に示す。ただし、標準化した值を用い た。その結果、堅確な組織である平織、柔軟で表面状態の感 覚がやや弱い組織である10枚朱子織、ほぼ中間に位置するそ の他の織物の 3 つのパターンに分類できるように思われる。 この結果は、クラスター分析を行った結果とも、ほぼ一致し た。

\section{4. 結 論}

各種織物の力学的性質、風合いに及ぼす織物組織の影響を 調バるため、「KES-FBシステム」を用い検討した結果、以下の 結論を得た。

(1)織物の組織構成のうち主として交錯堅確度、平均浮き長 と織物の力学的特性値、基本風合い值との間の関係を調 バた結果、織物組織は特に曲げ特性、せ九断特性、HARI、 SHINAYAKASAに影響する。関係のあるものについては、 重回帰分析を行い、重回帰式を求めた。両者の標準偏回 帰係数の比較から交錯堅確度の影響の方が、大であるこ とも分かった。これらの重回帰式を用いて織物の設計が 可能と思われる。

(2)主成分分析の結果、布のソフトさ、表面状態の感覚、伸 び柔らかさが、各種織物の力学的特性、風合いに影響を 及ぼすことが、さらに、織物は、堅確な組織である平織、 柔㳄で表面状態の感覚がやや弱い組織である10枚朱子織、 ほぼ中間に位置するその他の織物の 3 つのパターンに分 類できることが分かった。

\section{5 . 参考文献}

[1] 川端季雄；繊械誌，26, 721 (1973)

[2] Kawabata, Sueo; "HESC Standard of Hand Evaluation "Vol. 2 (H.V. Standard for women's Thin-Dress Fabric), HESC, The Textile Machinery Society of Japan, Osaka, Japan (1980)

[3] 丹羽雅子;アパレル科学 美しく快適な被服を科学する， 朝倉書店 (1997)

[4] S. Kawabata, K. Ito and M. Niwa ; J. Text. Inst. , 83, 361 (1992)

[5] 松平光男, 埴生千賀子；䋐消誌，36，348(1995)

[6] 松平光男, 埴生千賀子; 䋐消誌, 36, 588(1995)

[7] 日本産業皮膚衛生協会技術委員会第 1 分科分; 繊消誌, $6,443(1998)$

[8] Mitsuo Matsudaira ; J. Text. Inst. , 85, 158 (1994)

[9] R. H. Gong and S. K. Mukhopadyay ; J. Text. Inst. , 84, 192 (1993)

[10] Mi tsuo. Matsudaira and Masao Matsui ; J. Text. Inst. , 83, 144 (1994)

[11]渡辺綱夫；改訂被服材料学, 高陵社 (1991)

[12] 小川安朗; 応用被服材料学一消費性能を主として一, 光生 館, P. 65 (1967)

[13]川端季雄, 丹羽雅子; 瀻機誌, 37, 113(1984)

[14] 長谷川勝也; これならわかる多変量解析, 技術討論社, P. 42 (2002)

[15]福井三郎, 山岡昭美, 岡田文夫, 折井正規; 推計学入門演習, 産業図書(1996)

[16] 日本科学技術研修所; JUSE-MAによる多変量解析，日科技 連出版社 (1997)

[17]内田 治 ; すぐわかる EXCEL による多変量解析, 東京図 書 (1998) 